Article

\title{
In Vitro Evaluation of Chemically Analyzed Hypericum Triquetrifolium Extract Efficacy in Apoptosis Induction and Cell Cycle Arrest of the HCT-116 Colon Cancer Cell Line
}

\author{
Shahinaz Mahajna ${ }^{1,2,+}$, Sleman Kadan ${ }^{1,3,+}{ }^{\text {, Zipora Tietel }}{ }^{4}$, Bashar Saad ${ }^{1,5}{ }^{\circledR}$, Said Khasib ${ }^{5}$, \\ Aziz Tumeh ${ }^{5}$ (0), Doron Ginsberg ${ }^{2}$ and Hilal Zaid ${ }^{1,5, *}$ \\ 1 Qasemi Research Center, Al-Qasemi Academic College, P.O. Box 124, Baqa El-Gharbia 30100, Israel; \\ shahinaz_mh@hotmail.com (S.M.); slemanka@gmail.com (S.K.); bashar@qsm.ac.il (B.S.) \\ 2 The Mina and Everard Goodman Faculty of Life Science, Bar Ilan University, Ramat Gan 5299, Israel; \\ Doron.Ginsberg@biu.ac.il \\ 3 Casali Center for Applied Chemistry, Institute of Chemistry, The Hebrew University of Jerusalem, \\ Givat Ram, Jerusalem 91904, Israel \\ 4 Department of Postharvest Science of Fresh Produce, ARO, The Volcani Center, Bet Dagan 7505101, Israel; \\ tietel@volcani.agri.gov.il \\ 5 Faculty of Sciences, Arab American University, P.O. Box 240, Jenin 009704, Palestine; \\ said.khasib@aaup.edu (S.K.); aziztumeh@gmail.com (A.T.) \\ * Correspondence: hilalz@qsm.ac.il; Tel.: +972-4-628-6761 (ext. 6765) \\ + These authors contributed equally to this work.
}

Academic Editor: Nazim Sekeroglu, Anake Kijjoa and Sevgi Gezici

Received: 25 September 2019; Accepted: 12 November 2019; Published: 15 November 2019

\begin{abstract}
Naturally derived drugs and plant-based products are attractive commodities that are being explored for cancer treatment. This in vitro study aimed to investigate the role of Hypericum triquetrifolium ( $50 \%$ ethanol: $50 \%$ water) extract (HTE) treatment on apoptosis, cell cycle modulation, and cell cycle arrest in human colon cancer cell line (HCT-116). HTE induced cell death via an apoptotic process, as assayed by an Annexin V-Cy3 assay. Exposing HCT-116 cells to 0.064, 0.125, 0.25, and $0.5 \mathrm{mg} / \mathrm{mL}$ of HTE for $24 \mathrm{~h}$ led to $50 \pm 9 \%, 71.6 \pm 8 \%, 85 \pm 5 \%$, and $96 \pm 1.5 \%$ apoptotic cells, respectively. HCT-116 cells treated with 0.25 and $0.5 \mathrm{mg} / \mathrm{mL}$ HTE for $3 \mathrm{~h}$ resulted in $38.9 \pm 1.5 \%$ and $57.2 \pm 3 \%$ cleavage of caspase-3-specific substrate, respectively. RT-PCR analysis revealed that the HTE extract had no effect on mRNA levels of Apaf- 1 and NOXA. Moreover, the addition of $0.125 \mathrm{mg} / \mathrm{mL}$ and $0.25 \mathrm{mg} / \mathrm{mL}$ HTE for $24 \mathrm{~h}$ was clearly shown to attenuate the cell cycle progression machinery in HCT-116 cells. GC/MS analysis of the extract identified 21 phytochemicals that are known as apoptosis inducers and cell cycle arrest agents. All the compounds detected are novel in H. triquetrifolium. These results suggest that HTE-induced apoptosis of human colon cells is mediated primarily through the caspase-dependent pathway. Thus, HTE appears to be a potent therapeutic agent for colon cancer treatment.
\end{abstract}

Keywords: apoptosis; colon cancer; cell cycle; phytochemicals; Hypericum triquetrifolium

\section{Introduction}

Cancer is the second leading cause of mortality in humans worldwide. It is estimated that one in three women and one in two men in the United States will develop cancer in their lifetime. An increase in the number of individuals diagnosed with cancer each year, Due to population growth and a higher life expectancy, there has been an increase in the number of individuals diagnosed with cancer each year, but, coupled with improving survival rates, the number of cancer-survivors has increased as well $[1,2]$. 
Colorectal cancer (CRC) is the second leading cause of cancer death. The development of CRC proceeds through one or a combination of three different mechanisms: chromosomal instability, epigenetic instability pathway named CpG island methylator phenotype, and microsatellite instability. Chromosomal instability pathway begins with the loss in functionality of the Adenomatous Polyposis Coli (APC) gene genes are italicized, which is a tumor suppressor gene [3]. This is followed by the inactivation of the p53 gene (a sensor essential for the checkpoint control that arrests cells with damaged DNA in the G1 phase), which results in the formation of polyps on the inside of the colon wall. Although much has yet to be understood as to why some individuals develop CRC while others do not, certain genetic and environmental factors are known to increase a person's chance of developing the disease [1].

Surgery, chemotherapy, and radiotherapy, either individually or combined, were considered as conventional strategies for cancer treatment in the last century. With the rapid development of molecular medicine, novel therapeutic approaches such as immunotherapy, molecular targeted therapy, and hormonal therapy have been proposed to improve clinical outcomes for cancer patients. However, these therapeutic approaches are not always effective and survival rates are still poor [1,2]

There has been a substantial increase in the use of complementary and alternative medicines, including dietary supplements and medicinal plants, for cancer treatment. Several in vitro, cellular, and animal studies have examined the effects of herbal and other specialty products on the development and progression of CRC [3-5].

The use of agents targeting the cell cycle machinery has long been considered an ideal strategy for cancer therapy. These drugs target the abnormal expression of cyclin-dependent kinases (CDKs), mitotic kinases/kinesins, or they affect cellular checkpoints, resulting in cell cycle arrest and the subsequent induction of apoptosis in cancer cells. Cell-cycle-based agents can be grouped into categories that reflect their molecular targets. For example, CDK inhibitors target the inhibition of CDKs, which selectively block tumor growth without compromising normal cells; checkpoint inhibitors target the $S$ and G2 checkpoints, and mitotic inhibitors affect mitosis [6-8]. Another key player in the cyclins-CDKs assembly is retinoblastoma protein $(\mathrm{Rb})$. Phosphorylated $\mathrm{Rb}$ enhances E2F-1 to translocate into the nucleus and transcribe genes needed to switch the cell from $\mathrm{G} 1$ to $S$ phase $[9,10]$. Indeed, overexpression of E2F-1, CDKs and cyclins in carcinoma are associated with the progression of metastasis [11-13]. Moreover, Natural and synthetic drugs were reported to prevent colon cancer cell growth by inhibiting the expression of key cell cycle regulating proteins such as, CDK2, cyclins E2F-1 [10,14,15].

Apoptosis induction is a useful mechanism for modulating cancer progression, especially when there are mutations that alter the ability of the cell to undergo apoptosis and allow transformed cells to keep proliferating rather than dying. It would be therapeutically advantageous to tip the balance in favor of apoptosis over mitosis in tumors, if possible. The progressive accumulation of genetic alterations (APC, p53, and ras) governs the transition of the normal colorectal epithelium to adenocarcinomas [16].

Herbal medicines such as garlic, onion, black fennel seeds, olive oil, olive leaves, as well as HTE, are prescribed for cancer treatment and prevention $[17,18]$. Hypericum triquetrifolium is also commonly used to treat inflammation, septic shock depression and nociception [19]. In addition, several studies have reported the efficacy of Hypericum genus in apoptosis induction in several cancer cell lines. For instance by active compounds from Hypericum ascyron $\mathrm{L}$ was effective in apoptosis induction in in human cervical carcinoma HeLa cells [20]. Intriguingly, Hypericum elodeoides augmented apoptosis in HeLa Cell through Caspase-8 Activation and PARP Cleavage [21]. Cisplatin and the hypericin found in Hypericum perforatum exhibited a dose-dependent cytotoxic and apoptotic effect in the MCF-7 cell line [22]. Moreover, Hypericum adenotrichum Spach [23], Hypericum scabrum L. [24] and Hypericum japonicum [25] induced apoptosis in several cancer cell lines in vitro. Despite the progress of modern medicine, traditional medicine is still being practiced [26]. However, the safety and effectiveness of alternative medicine are not always scientifically proven. Based on the knowledge of traditional herbal medicine and on preliminary studies, this in vitro study aimed to investigate the role of Hypericum triquetrifolium (50\% ethanol: 50\% water) extract (HTE) treatment on apoptosis, cell cycle modulation, and cell cycle arrest in a human colon cancer cell line (HCT-116). 


\section{Materials and Methods}

\subsection{Materials}

Cells of the human colorectal cell line HCT-116 (ATCC ${ }^{\circledR}$ CCL-247'M $)$ were purchased from the ATCC (Manassas, VA, USA). All tissue culture reagents, including fetal bovine serum and standard culture medium RPMI-1640, were purchased from Biological Industries (Beit Haemek, Israel). An LDH kit was purchased from Promega (Madison, WI, USA); a cell cycle kit was purchased from Thermo Fisher (Waltham, MA, USA); and an RNA isolation kit was purchased from QIAGEN (Hilden, Germany). MTT reagent and all other materials were purchased from Sigma Aldrich (St. Louis, MO, USA). HTE (aerial parts) was purchased from Al Alim-Medicinal Herb Center, Zippori, Israel.

\subsection{Preparation of Plant Extracts}

One hundred g of air-dried HTE plant material was added to $1 \mathrm{~L}$ of $50 \% \mathrm{EtOH}$ (in water) and boiled for $30 \mathrm{~min}$, then stirred for $24 \mathrm{~h}$ at room temperature. The obtained extract was filtered through filter paper, aliquoted, and frozen at $-80^{\circ} \mathrm{C}$ until use $[27,28]$.

\subsection{Silylation Derivatization}

The dried extract sample was re-dissolved and derivatized in a solution of $40 \mu \mathrm{L}$ of $20 \mathrm{mg} / \mathrm{mL}$ methoxyamine hydrochloride in pyridine for $90 \mathrm{~min}$ at $370{ }^{\circ} \mathrm{C}$, followed by a $30 \mathrm{~min}$ treatment with $70 \mu \mathrm{L}$ of N-methyl-N(trimethylsilyl)trifluoroacetamide (MSTFA) at $37^{\circ} \mathrm{C}$ and centrifugation. $1 \mu \mathrm{L}$ of the derivatized sample was injected into the gas chromatograph coupled with a mass selective detector (GC/MS) [29].

\subsection{Gas Chromatography-Mass Spectrometry Analysis}

The GC/MS system was comprised of a COMBI PAL autosampler (CTC Analytics, Zwingen, Switzerland), a Trace GC Ultra gas chromatograph equipped with a programmed temperature vaporizer (PTV) injector, and a DSQ quadrupole mass spectrometer (ThermoElectron Cooperation, Austin, TX, USA). GC analysis was performed on a Zebron ZB-5ms (30 $\mathrm{m} \times 0.25 \mathrm{~mm} \times 0.25 \mu \mathrm{m}) \mathrm{MS}$ column (Phenomenex, Torrance, CA, USA). The PTV split technique was carried out as follows: sugars were analyzed with a split of 1:100, and the lower abundance compounds were analyzed with a split of 1:10. The following temperature program was employed: the PTV inlet temperature was set to $45^{\circ} \mathrm{C}$ and held there for $0.05 \mathrm{~min}$, followed by a temperature increase to $70^{\circ} \mathrm{C}$, with a ramp rate of $10^{\circ} \mathrm{C} / \mathrm{s}$. The PTV inlet was held at $70{ }^{\circ} \mathrm{C}$ for $0.25 \mathrm{~min}$, followed by a transfer-to-column stage, whereby the temperature was increased to $270^{\circ} \mathrm{C}$, with a ramp rate of $14.5^{\circ} \mathrm{C} / \mathrm{s}$, and held there for $0.8 \mathrm{~min}$. Finally, a cleaning stage was carried out by raising the temperature to $330{ }^{\circ} \mathrm{C}$, with a ramp rate of $10{ }^{\circ} \mathrm{C} / \mathrm{s}$, and maintaining it for $10 \mathrm{~min}$.

The interface was heated to $300{ }^{\circ} \mathrm{C}$, and the ion source was adjusted to $250{ }^{\circ} \mathrm{C}$. Helium was used as the carrier gas at a flow rate of $1.2 \mathrm{~mL} / \mathrm{min}$. The analysis was performed using the following temperature program: $1 \mathrm{~min}$ isothermal at $40{ }^{\circ} \mathrm{C}$, followed by an increase to $320{ }^{\circ} \mathrm{C}$ at a $15{ }^{\circ} \mathrm{C} / \mathrm{min}$ ramp rate, and then maintaining this temperature for $4.5 \mathrm{~min}$. Mass spectra were recorded at $9 \mathrm{scans} / \mathrm{s}$ in the $m / z$ 40-450 scanning range from 5 till $10 \mathrm{~min}$, and in the $\mathrm{m} / \mathrm{z}$ 50-600 scanning range from 10 till $24 \mathrm{~min}$. For the analysis of the lower abundance compounds, the filament was switched off from 12.95 to $13.60 \mathrm{~min}$ in order to prevent damage to the MS detector from the high concentration of sugar compounds [29].

\subsection{Identification of Components}

Phytochemical compounds were putatively identified by a correlation of their retention index (RI) and mass spectrum to those present in the mass spectra library of the Max-Planck-Institute for Plant Physiology (Golm, Germany; Q_MSRI_ID, http://csbdb.mpimp-golm.mpg.de/csbdb/gmd/msri/ 
gmd_msri.html) and the commercial mass spectra library NIST05 (http://www.nist.gov/). The response values for metabolites resulting from the Xcalibur processing method were normalized to the ribitol internal standard $[29,30]$.

\subsection{Cell Culture}

Human colorectal cell line HCT-116 were grown in Roswell Park Memorial Institute (RPMI)-1640 medium with a high glucose content $(4.5 \mathrm{~g} / \mathrm{L})$ and supplemented with: $10 \% v / v$ fetal calf serum, $1 \%$ nonessential amino acid, $1 \%$ glutamine, and $100 \mathrm{U} / \mathrm{mL}$ penicillin. The cells were maintained in a humidified atmosphere of $5 \% \mathrm{CO}_{2}$ at $37^{\circ} \mathrm{C}$.

\subsection{MTT (Cell Viability)}

The tetrazolium dye MTT method is a colorimetric assay based on the conversion of the yellow tetrazolium bromide to its purple formazan derivative by mitochondrial succinate dehydrogenase in viable cells. 20,000 cells were seeded per well of 96-microtiter plates. $24 \mathrm{~h}$ after cell seeding, the cells were incubated with increasing concentrations of plant extract $(0-1000 \mu \mathrm{g} / \mathrm{mL})$ for $24 \mathrm{~h}$ at $37^{\circ} \mathrm{C}$. The cells were then washed in phosphate-buffered saline and incubated in serum-free RPMI. After this, $0.5 \mathrm{mg} / \mathrm{mL}$ MTT was added to each well $(100 \mu \mathrm{L})$ and incubated for $4 \mathrm{~h}$. Afterward, the medium was removed, and the cells were incubated for 15 min with $100 \mu \mathrm{L}$ of acidic isopropanol $(0.08 \mathrm{~N} \mathrm{HCl})$, in order to dissolve the formazan crystals. The absorbance of the MTT formazan was measured at $570 \mathrm{~nm}$ in a microtiterplate reader. Viability was defined as the ratio (expressed as a percentage) of absorbance of treated cells to untreated cells [31].

\subsection{Lactate Dehydrogenase}

Lactate dehydrogenase (LDH) assay measures the leakage of the LDH enzyme, which is normally found in the cytoplasm, into the extracellular medium as an indication for plasma membrane rupture. LDH activity was measured in both the supernatants and the cell lysate fractions using CytoTox 96, a non-radioactive cytotoxicity assay kit (Promega), in accordance with the manufacturer's instructions. The absorbance was measured at $490 \mathrm{~nm}$ with a 96-well microtiterplate reader (Anthos, Biochrom, Cambridge, UK) [31].

\subsection{Apoptosis Detection}

HCT-116 cells were seeded in a 24-well plate and incubated with HTE $(0-500 \mu \mathrm{g} / \mathrm{mL})$ for $24 \mathrm{~h}$, followed by apoptosis detection using Acridine Orange (green) and Annexin-V CY3 (red) dyes, according to the manufacture's protocol. Annexin V-Cy3 Apoptosis Detection Kit (abcam, Cambridge, UK) is based on the observation that soon after initiating apoptosis, cells translocate the membrane phospholipid phosphatidylserine (PS) from the inner face of the plasma membrane to the cell surface. Once at the cell surface, PS can be easily detected by staining with a fluorescent conjugate of Annexin V, a protein that has a high affinity for PS. The detection of the stained PS was carried out by fluorescence microscopy [32].

\subsection{Caspase-3 Activity Assay}

HCT-116 cells were treated as described in Section 2.9 and caspase-3 activity was detected according to the manufacturer's protocol. Caspase-3 Colorimetric assay (Sigma-Aldrich) is based on the hydrolysis of the peptide substrate acetyl-Asp-Glu-Val-Asp p-nitroanilide (Ac-DEVD-pNA) by caspase-3, which results in the release of the $p$-nitroaniline (pNA) moiety. The concentration of pNA was calculated from the absorbance measured at $405 \mathrm{~nm}$ with a 96-well microtiterplate reader [33]. 


\subsection{Cell Cycle Assay}

HCT-116 cells were treated as described in Section 2.9. The cells were stained with a fluorescence ubiquitination cell cycle indicator (FUCCI, Premo FUCCI Cell Cycle Sensor, BacMam 2.0) according to the manufacturer's instructions, in order to detect the cell cycle stages. This indicator employs red (RFP) and green (GFP) fluorescent proteins fused to different regulators of the cell cycle: Cdt1 and geminin. In the G1 phase of the cell cycle, only Cdt1 tagged with RFP may be visualized, thus identifying cells in the G1 phase with red fluorescent nuclei. In the S, G2 and M phases, Cdt1 is degraded and only geminin tagged with GFP remains, thus identifying cells in these phases with green fluorescent nuclei. During the G1/S transition, both proteins are present in the cells, allowing GFP and RFP fluorescence to be observed together as yellow fluorescence. The cells monitored under fluorescent microscope [34].

\subsection{FACS Analysis}

HCT-117 cells were seeded in a 24-well plate and a day after they were treated with the plant extract $(0-250 \mu \mathrm{g} / \mathrm{mL})$ for $24 \mathrm{~h}$, trypsinized and fixed with $70 \%$ ethanol. After fixation, cells were centrifuged and incubated for $4 \mathrm{~min}$ at $1500 \mathrm{rpm}$ at $4{ }^{\circ} \mathrm{C}$. Then, the cells were suspended with $5 \mathrm{mg} / \mathrm{mL}$ propidium iodide and $50 \mu \mathrm{g} / \mathrm{mL}$ RNase A. After $20 \mathrm{~min}$ incubation at room temperature, fluorescence was measured using Becton Dickinson flow cytometer [35].

\subsection{Total RNA Isolation and $c D N A$ Synthesis}

HCT-116 cells were treated as described in Section 2.9. Total RNA was isolated from the cells using Rneasy Plus Mini Kit (QIAGEN) according to the manufacturer's instructions, and immediately frozen at $-80^{\circ} \mathrm{C}$ until further use. DNase-treated RNAs were used to synthesize cDNA with the Transcriptor First Strand cDNA Synthesis Kit, using random hexamers as specified by the manufacturer (Maxima First Strand cDNA Synthesis Kit for RT-PCR by Thermo).

Real-time PCR amplification (RT-PCR) and advanced relative quantification analysis were achieved using a Light Cycler 480 instrument (Roche Applied Science, Penzberg, Germany) with software version LCS480 1.5.039. All reactions were performed in duplicate with the Light Cycler Fast Start DNA Master SYBER Green I Kit (Roche Applied Science) in a final $20 \mu \mathrm{L}$ volume with $2.5 \mathrm{mM} \mathrm{MgCl}{ }_{2}$, $0.2 \mu \mathrm{M}$ of each primer and $2 \mu \mathrm{L}$ cDNA. Amplification conditions consisted of an initial pre-incubation step at $95{ }^{\circ} \mathrm{C}$ for $10 \mathrm{~min}$ (polymerase activation), followed by amplification of the target cDNA for 45 cycles $\left(95^{\circ} \mathrm{C}\right.$ for $15 \mathrm{~s}, 60^{\circ} \mathrm{C}$ for $20 \mathrm{~s}$, and extension time at $72{ }^{\circ} \mathrm{C}$ for $\left.30 \mathrm{~s}\right)$ [35]. the primer sequences (5' to $\left.3^{\prime}\right)$ for qPCR amplification were:

- Apaf-1 for-AACCAGGATGGGTCACCATA

- Apaf-1 rev-ACTGAAACCCAATGCACTCC

- NOXA for-CAGAGCTGGAAGTCGAGTG

- NOXA rev-CAGGTTCCTGAGCAGAAGAG

\subsection{Statistical Analysis}

Error limits were cited, and error bars were plotted and represent simple standard deviations of the mean. When comparing different samples, results were considered to be statistically different when $P<0.05$. Student $t$-test was applied for statistical calculations using SPSS version 21.0 (Armonk, NY, USA)

\section{Results Sections in Wrong Order-Experimental Is Last-Renumber Everythi8ngn}

\subsection{The Affects HCT-116 Cell Viability}

The effect of HTE on cell viability was evaluated in the HCT-116 colon cancer cell line using MTT and LDH assays. Cells seeded in 96-well plates (20,000 cells/well) were exposed to increasing concentrations $(0-1 \mathrm{mg} / \mathrm{mL})$ of HTE for $24 \mathrm{~h}$. Concentrations that led to less than $10 \%$ of cell death 
were considered non-toxic. HTE was determined to be non-toxic up to $0.5 \mathrm{mg} / \mathrm{mL}$ and the $\mathrm{IC}_{50} \mathrm{was}$ $\sim 1 \mathrm{mg} / \mathrm{mL}$ (Figure 1). HTE concentrations higher than $0.5 \mathrm{mg} / \mathrm{mL}$ caused a significant reduction in cell viability.

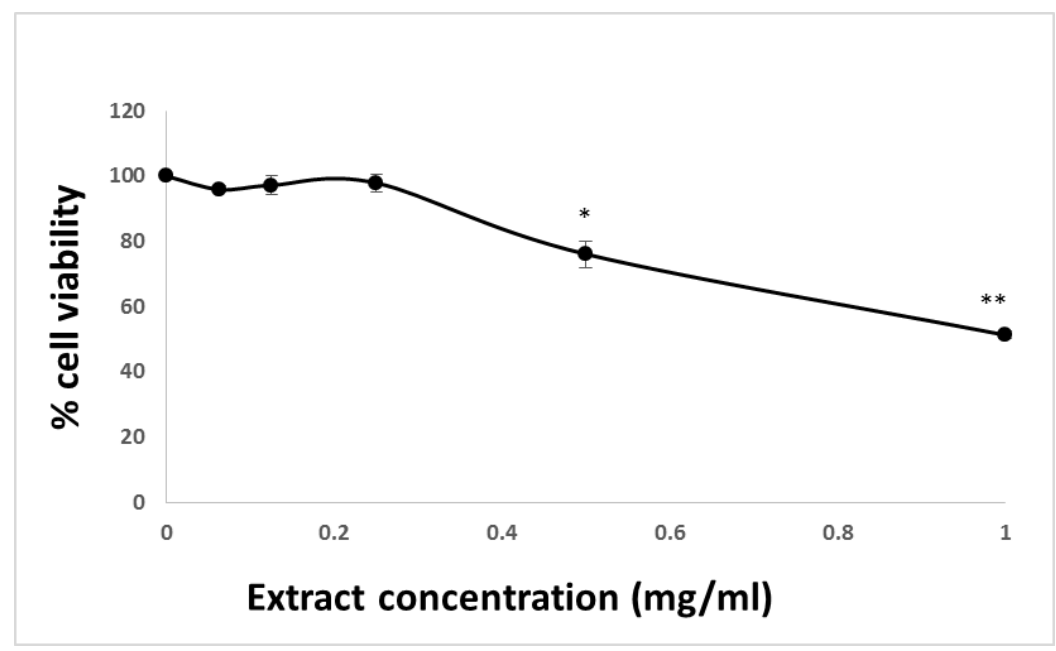

Figure 1. MTT assay of HCT-116 cells after $24 \mathrm{~h}$ treatment with varying concentrations of HTE. The absorbance of the MTT formazan was measured at $620 \mathrm{~nm}$ using microtiterplate reader. Cell viability was defined as the absorbance ratio (expressed as a percentage) of treated cells to untreated cells. Values represent the mean $\pm \mathrm{SD}$ of three independent experiments carried out in triplicates. ${ }^{*} p<0.05$, ** $p<0.01$, significant as compared with controls.

Membrane integrity can be evaluated by measuring LDH activity. LDH, an enzyme located in the cytoplasm, catalyzes the conversion of lactate to pyruvate. When LDH is found in the media of the cells, there are two possible causes: (1) cellular death or (2) a leak in the cell membrane. HCT-116 cells seeded in a 96 -well plate $(20,000$ cells/well) were exposed to increasing concentrations $(0-1 \mathrm{mg} / \mathrm{mL})$ of HTE for $24 \mathrm{~h}$. In accordance with the MTT results, no significant change in LDH levels was detected in the culture medium after exposure to extracts of HTE at concentrations of up to $0.25 \mathrm{mg} / \mathrm{mL}$ (Figure 2). Based on the MTT and LDH assay results, HTE was used in concentrations no greater than $0.5 \mathrm{mg} / \mathrm{mL}$ in the ensuing experiments.

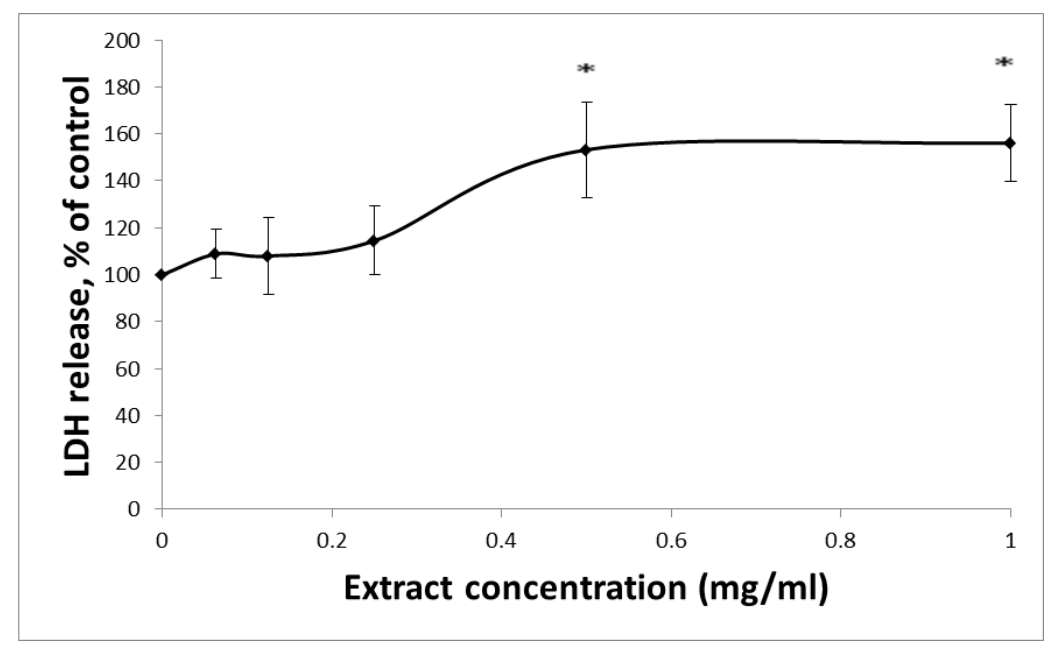

Figure 2. LDH leakage from HCT-116 cells after $24 \mathrm{~h}$ incubation with varying concentrations of HTE. The leakage of LDH into the extracellular medium is measured. The absorbance was measured at $492 \mathrm{~nm}$ using a microtiterplate reader. Values represent the mean $\pm \mathrm{SD}$ of three independent experiments carried out in triplicates. ${ }^{*} p<0.05$, significant as compared with controls. 


\subsection{HTE Induces Apoptosis in HCT-116 Cells}

Annexin-V detects cells in early apoptosis stages via membrane-associated processes, by binding to PS head groups. An Annexin test was performed on HCT-116 cell line after exposure to 0.064, 0.125, 0.25 , and $0.5 \mathrm{mg} / \mathrm{mL}$ of HTE. Characteristically, Annexin-V binds only to the surface of the HCT-116 cell membrane in apoptotic cells, where it binds to the exposed PS head groups [32]. As shown in Figure 3B, when compared with control treated cells, treatment of HCT-116 cells with HTE ( 0.125 and $0.25 \mathrm{mg} / \mathrm{mL}$ for $24 \mathrm{~h}$ ) resulted in a significant increase of apoptosis (red membrane). Indeed, HTE induced $50 \pm 9 \%, 71.6 \pm 8 \%, 85 \pm 5 \%$, and $96 \pm 1.5 \%$ apoptosis at concentrations of $0.064,0.125,0.25$, and $0.5 \mathrm{mg} / \mathrm{mL}$ (Figure $3 \mathrm{~A}, \mathrm{~B}$ ). The putative apoptosis inducer structures and names are shown in Figure 3C. Most of the compounds are fatty acids and phenols as determined by GC/MS.

To further assess HTE's ability to induce apoptosis, its effect on caspase-3 activation in HCT-116 cells was analyzed. As shown in Figure 4, treatment of HCT-116 cells with 0.25 and $0.5 \mathrm{mg} / \mathrm{mL}$ of HTE, for $3 \mathrm{~h}$ resulted in $38.9 \pm 1.5 \%$ and $57.2 \pm 3 \%$ cleavage of caspase-3-specific substrate, respectively. Staurosporine, which is commonly used as a positive control for apoptosis induction, $(1 \mu \mathrm{M})$ led to $100 \%$ apoptosis. These results are in line with the previous Annexin V-Cy3 apoptosis detection results. Put together, these results indicate that HTE's ability to induce apoptosis in HCT-116 cells is mediated, at least in part, through the activation of caspase-3.

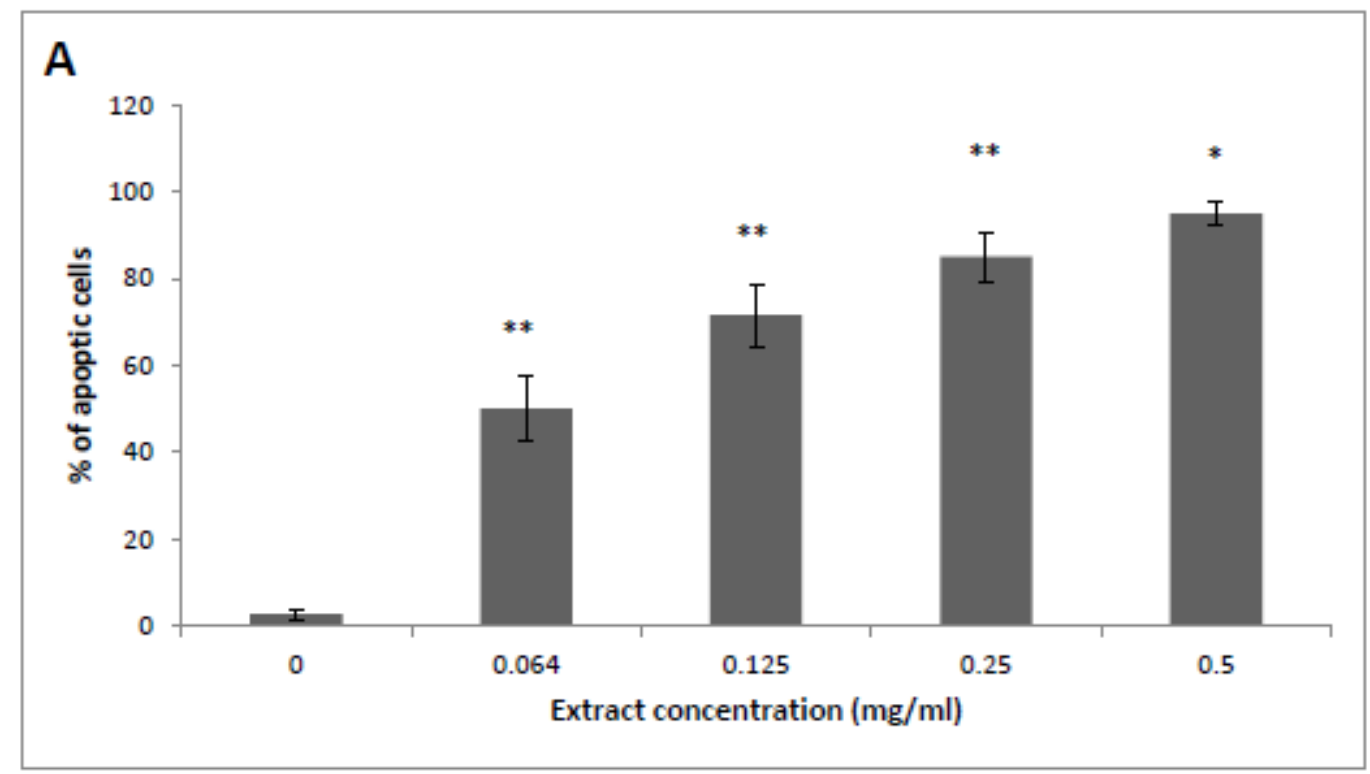

B

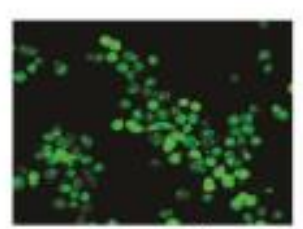

control

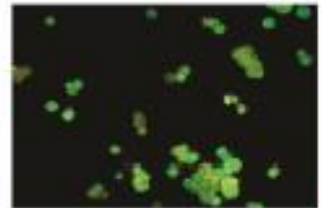

$0.064 \mathrm{mg} / \mathrm{ml}$

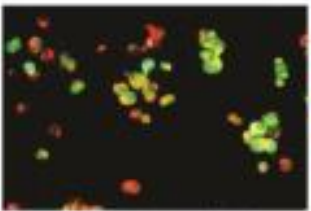

$0.125 \mathrm{mg} / \mathrm{ml}$

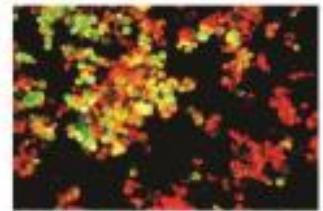

$0.25 \mathrm{mg} / \mathrm{ml}$

Figure 3. Cont. 
C<smiles>CCCCCC(=O)O</smiles>

Hexanoic acid<smiles>OCc1ccccc1</smiles>

Benzyl alcohol

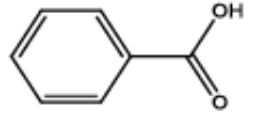

Benzoic acid<smiles>CCCCCCCCC(=O)O</smiles><smiles>Oc1cc(O)cc(O)c1</smiles>

Phloroglucinol<smiles>CC(O)C(O)C(O)C(O)C=O</smiles>

D-Rhamnose<smiles>CCCCCCCCCCCCC(=O)O</smiles>

Palmitic acid<smiles>O[C@H]1[C@H](O)[C@H](O)[C@H](O)[C@@H](O)[C@H]1O</smiles>

myo-Inositol

Figure 3. Determination of apoptosis induced by HTE in HCT-116 cells. Cells were exposed to the plant extract (up to $0.25 \mathrm{mg} / \mathrm{mL}$ ) for $24 \mathrm{~h}$. Apoptosis was determined using Acridine Orange (green) and Annexin-V CY3 (red) staining assay and was monitored by a fluorescence microscope. Apoptosis is expressed as a percentage of treated cells to untreated cells. (A) Values represent the mean $\pm \mathrm{SD}$ of three independent experiments carried out in triplicates. ${ }^{*} p<0.05,{ }^{* *} p<0.01$, significant as compared with controls. (B) Representative fluorescence microscopy images showing co-staining with Acridine Orange and Annexin-V CY3. (C) Chemical structures of the detected putative apoptotic inducer compounds.

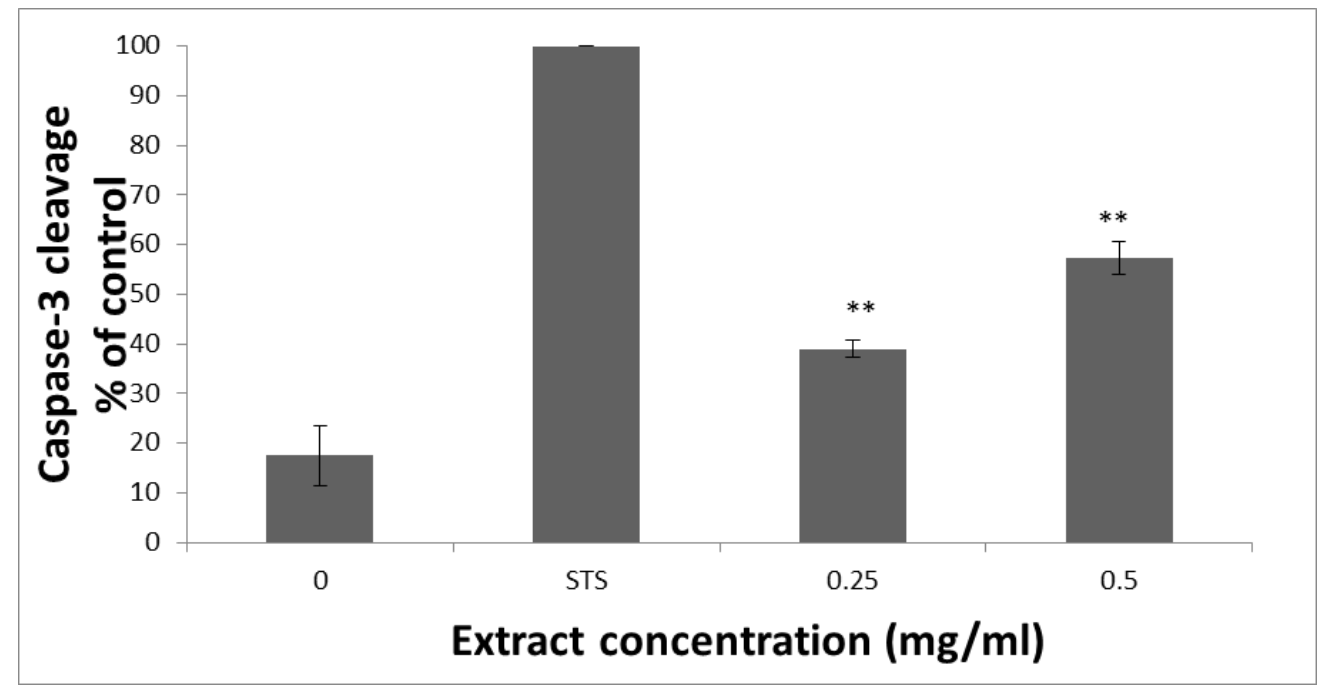

Figure 4. Analysis of intracellular caspase-3 activity in HCT-116 cells after $3 \mathrm{~h}$ post-treatment with staurosporine $(1 \mu \mathrm{M})$ and HTE. Cell lysates were combined with the caspase-3-specific substrate in a standard reaction buffer. Cleavage of the caspase-3-specific substrate was compared to the staurosporine (STS, $1 \mu \mathrm{M}$ ) treated cells. The absorbance was measured at $405 \mathrm{~nm}$ using a microtiterplate reader. Values represent the mean $\pm \mathrm{SD}$ of three independent experiments carried out in triplicates. ** $p<0.01$-significant as compared with control.

\section{3. mRNA Levels of Apaf-1 and NOXA}

Next, the effect of HTE on the expression of apoptotic protease-activating factor-1 (Apaf-1) and NOXA, two proteins involved in the intrinsic apoptosis pathway, was examined. mRNA levels 
of Apaf-1 and NOXA were detected by RT-PCR and normalized to glyceraldehyde 3-phosphate dehydrogenase (GAPDH) levels. RT-PCR analysis showed HTE had no effect on Apaf-1 and NOXA mRNA levels (data not shown).

\subsection{HTE Modulates the Cell Cycle}

The effect of HTE on HCT-116 cell cycle was tested using FACS analysis. Cells were exposed to 0.125 and $0.25 \mathrm{mg} / \mathrm{mL}$ of HTE for 4, 8, and $24 \mathrm{~h}$. Treatment of HCT- 116 cells with HTE at concentrations of 0.125 and $0.25 \mathrm{mg} / \mathrm{mL}$ for $24 \mathrm{~h}$ resulted in a significantly higher level of sub G1 phase $(21.7 \pm 4.8 \%$ and $23.24 \pm 3.9 \%$, respectively), compared to non-treated cells $(0.46 \pm 0.22)$ as shown in Figure $5 \mathrm{~A}, \mathrm{~B}$.

No significant changes in the percentage of cells in the S and G2-M phases were observed. Treatments for 4 and $8 \mathrm{~h}$ with HTE did not result in a significant effect on the cell cycle distribution and cell viability. For further examination of the role HTE plays in cell cycle modulation, the FUCCI Cell Cycle Sensor assay was employed. HCT- 116 cells challenged with 0.125 and $0.25 \mathrm{mg} / \mathrm{mL}$ HTE for $24 \mathrm{~h}$ were arrested in the G1 phase (red cells, Figure 5C). The putative cell cycle arresting compounds were found to be mainly terpenoids, phenols, and fatty acids as detected by GC/MS (Figure 5D). These compounds are also known as apoptotic inducers, except for dihydroxyacetone (Table 1).

A
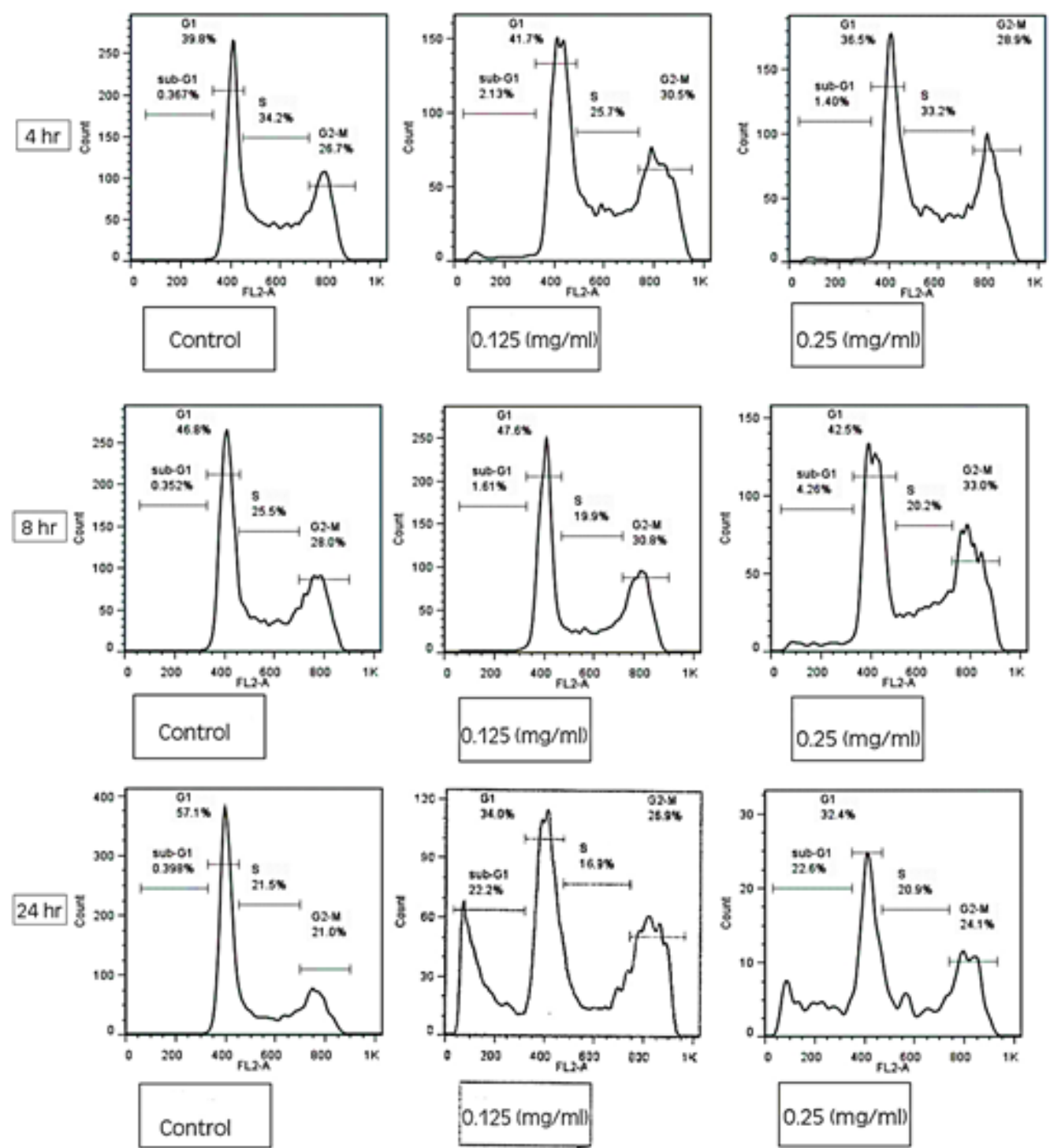

Figure 5. Cont. 
B

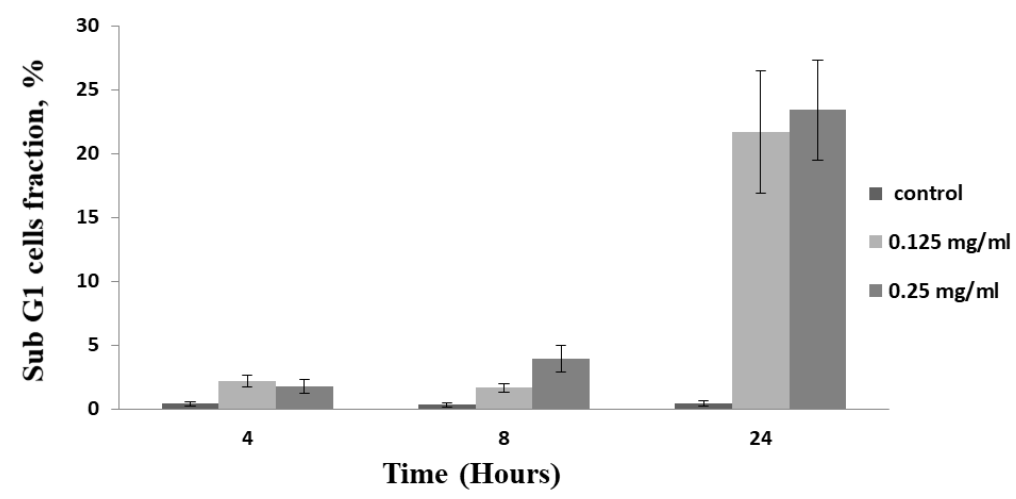

C

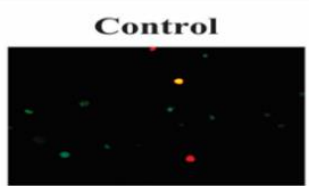

\section{H.triquetrifolium}

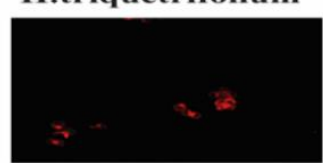

$0.125 \mathrm{mg} / \mathrm{ml}$

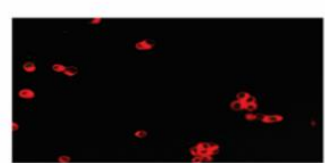

$0.250 \mathrm{mg} / \mathrm{ml}$

D<smiles>O=C([18OH])OC(=O)C(=O)CO</smiles><smiles>CC(=O)OCC(C)(C)O</smiles><smiles>CCCCOC(=O)c1ccccc1O</smiles><smiles>O=C(O)/C=C/c1ccc(O)cc1</smiles><smiles>CCC(/C=C/[C@H](C)[C@H]1CC[C@H]2[C@]3(C)CC=C4C[C@@H](O)CC[C@]4(C)[C@H]3CC[C@]12C)C(C)C</smiles>

Stigmasterol<smiles>O=C(O)/C=C\c1ccc(O)c(O)c1</smiles>

Caffeic acid<smiles>CCCCCCCCCCCCCCCCCCCCCCCCCCCCCCC</smiles>

Figure 5. The effect of HTE on cell cycle distribution of HCT-116 cells. (A) Cellular DNA was stained with propidium iodide and flow cytometric analysis was done to determine the cell cycle distribution post-treatment with HTE for 4, 8, and $24 \mathrm{~h}$. (B) The apoptotic fraction, the sub G1 phase of the cell cycle, is represented on the histograms. (C) Fluorescence images of HCT-116 cells using FUCCI Cell Cycle Sensor. Cells were treated with 0.125 and $0.25 \mathrm{mg} / \mathrm{mL}$ of HTE for $24 \mathrm{~h}$. Three critical phases can be observed in FUCCI: G0/G1 (Red), G1/S (yellow), and G2/M (Green). (D) Chemical structure of the detected putative cell cycle arrest compounds. 
Table 1. Phytochemical profile of HTE and their association with anti-cancer, apoptosis induction, or cell cycle arrest activity.

\begin{tabular}{|c|c|c|c|c|c|c|c|}
\hline Peak & Name & $\mathbf{R}_{\mathbf{t}}$ & $\%$ Area & $\mathrm{DW} \mathrm{mg/g}$ & Match Factor & Relation to Apoptosis & References \\
\hline 1 & Pentanoic acid & 10.791 & 0.01 & 0.054207 & 89 & Its derivatives are used to induce apoptosis in cell lines. & [36] \\
\hline 2 & 2,3-Butanediol & 12.863 & 0.05 & 0.286145 & 98 & $\mathrm{~N} / \mathrm{A}$ & \\
\hline 3 & 1,3-Propanediol & 13.570 & 0.01 & 0.05732 & 88 & $\mathrm{~N} / \mathrm{A}$ & \\
\hline 4 & Lactic Acid & 13.819 & 0.14 & 0.891773 & 93 & $\mathrm{~N} / \mathrm{A}$ & \\
\hline 5 & Hexanoic acid & 14.002 & 0.04 & 0.276932 & 96 & $\begin{array}{l}\text { Also known as caproic acid. Reported to induce } \\
\text { apoptosis in human colorectal, skin, and breast cancer. } \\
\text { Moreover, it "could potentially be used to prevent } \\
\text { and/or treat these cancers". }\end{array}$ & [37] \\
\hline 6 & Succinimide & 15.525 & 0.01 & 0.060801 & 88 & $\mathrm{~N} / \mathrm{A}$ & \\
\hline 7 & Benzyl alcohol & 16.447 & 0.11 & 0.667908 & 91 & $\begin{array}{l}1 \% \text { benzyl alcohol was reported to induce high } \\
\text { apoptosis and necrosis in human dermal fibroblasts. }\end{array}$ & [38] \\
\hline 8 & 4-Hydroxybutanoic acid & 16.96 & 0.07 & 0.465751 & 86 & N/A & \\
\hline 9 & Glycerol & 17.956 & 6.27 & 39.74729 & 99 & $\mathrm{~N} / \mathrm{A}$ & \\
\hline 10 & 3-Hydroxybutanoic acid & 18.065 & 0.01 & 0.075168 & 92 & $\mathrm{~N} / \mathrm{A}$ & \\
\hline 11 & Dihydroxyacetone & 18.768 & 0.03 & 0.184817 & 78 & $\begin{array}{l}\text { Reported to induce G2/M arrest and apoptotic cell death } \\
\text { in melanoma A375P cell line. }\end{array}$ & [39] \\
\hline 12 & Benzoic Acid & 19.244 & 0.19 & 1.22039 & 98 & $\begin{array}{l}\text { Sodium benzoate was reported to activate NFkB and } \\
\text { induce apoptosis in HCT116 cells. }\end{array}$ & [40] \\
\hline 13 & Octanoic acid & 19.808 & 0.02 & 0.143862 & 83 & N/A & \\
\hline 14 & phosphoric acid & 20.467 & 3.85 & 24.42644 & 86 & $\mathrm{~N} / \mathrm{A}$ & \\
\hline 15 & 1,2,3-Butanetriol & 20.958 & 0.30 & 1.88296 & 98 & $\mathrm{~N} / \mathrm{A}$ & \\
\hline 16 & Nonanoic acid & 22.371 & 0.11 & 0.679532 & 87 & $\begin{array}{l}\text { Reported to induce apoptosis in vivo in epidermal } \\
\text { Langerhans. }\end{array}$ & [41] \\
\hline 17 & (E)-Erythrono-1,4-lacton & 22.971 & 0.04 & 0.230517 & 89 & $\mathrm{~N} / \mathrm{A}$ & \\
\hline 18 & Pyroglutamic acid & 25.973 & 0.69 & 4.36759 & 94 & $\mathrm{~N} / \mathrm{A}$ & \\
\hline 19 & L-Threitol & 26.515 & 0.09 & 0.581057 & 93 & $\mathrm{~N} / \mathrm{A}$ & \\
\hline 20 & meso-Erythritol & 26.698 & 0.33 & 2.11151 & 95 & $\mathrm{~N} / \mathrm{A}$ & \\
\hline 21 & 3-Hydroxybenzoic acid & 27.584 & 0.11 & 0.674429 & 85 & N/A & \\
\hline
\end{tabular}


Table 1. Cont

\begin{tabular}{|c|c|c|c|c|c|c|c|}
\hline Peak & Name & $\mathbf{R}_{\mathbf{t}}$ & $\%$ Area & $\mathrm{DW} \mathrm{mg} / \mathrm{g}$ & Match Factor & Relation to Apoptosis & References \\
\hline 22 & 4-Hydroxybenzoic acid & 29.078 & 0.36 & 2.265056 & 81 & $\begin{array}{l}\text { Detected in Schisandra chinensis fruit extract, which is } \\
\text { known to induce caspase-dependent apoptosis in } \\
\text { human ovarian cancer A2780 cells. It was also detected } \\
\text { in pinecones of Pinus koraiensis extract and exhibited } \\
\text { cytotoxic activity, with } \mathrm{IC}_{50} \text { value around } 1 \mathrm{mg} / \mathrm{mL} \text { in } \\
\text { four human lung cancer cell lines, A549, H1264, H1299, } \\
\text { and Calu-6. Similarly, Sitarek and colleagues reported } \\
\text { antiproliferative and cell cycle arrest activity on glioma } \\
\text { cells for the same compound in the root extract of } \\
\text { Leonurus sibiricus L. It increased Bax, Bcl-2, p53, } \\
\text { Caspases in glioma and breast cancer cell lines. }\end{array}$ & [42-45] \\
\hline 23 & Arabinonic acid, $\gamma$-lactone & 29.429 & 0.06 & 0.402076 & 89 & N/A & \\
\hline 24 & Phloroglucinol & 29.59 & 0.09 & 0.590668 & 92 & $\begin{array}{l}\text { Reported to induce apoptosis in distinct cancer cell } \\
\text { lines. }\end{array}$ & [46-48] \\
\hline 25 & Levoglucosan & 31.084 & 0.66 & 4.189809 & 95 & N/A & \\
\hline 26 & D-(-)-Rhamnose & 31.545 & 0.31 & 1.948759 & 94 & $\begin{array}{l}\text { Apoptosis inducer and anti-cancer agent, especially in } \\
\text { human breast cancer. }\end{array}$ & [49] \\
\hline 27 & Vanillic Acid & 31.962 & 0.71 & 4.500047 & 77 & An antioxidant and has some anti-cancer benefits. & [50] \\
\hline 28 & 2-Methoxy-1,3-dioxolane & 32.687 & 2.80 & 17.73789 & 91 & N/A & \\
\hline 29 & Methyl $\alpha$-D-glucofuranoside & 32.951 & 0.52 & 3.281267 & 86 & Close derivates are used for tumor treatment. & \\
\hline 30 & Protocatechuic acid & 33.068 & 0.25 & 1.559802 & 84 & $\begin{array}{l}\text { Known to induce apoptosis in human ovarian, breast, } \\
\text { lung, liver, cervix, and prostate cancer cells, as well as } \\
\text { others, by modulating FAK, MAPK, c-June, and NF- } \mathrm{B} B \\
\text { pathways.It was also reported to lead to cell cycle arrest. }\end{array}$ & [51-55] \\
\hline 31 & Shikimic acid & 33.068 & 0.46 & 2.892089 & 87 & N/A & \\
\hline 32 & Quininic acid & 33.998 & 13.41 & 85.04314 & 88 & $\mathrm{~N} / \mathrm{A}$ & \\
\hline 33 & D-Fructose & 34.364 & 18.78 & 119.1289 & 91 & $\mathrm{~N} / \mathrm{A}$ & \\
\hline 34 & $p$-Coumaric acid & 34.679 & 0.24 & 1.521807 & 89 & $\begin{array}{l}\text { Reported to induced apoptosis and cell cycle arrest in } \\
\text { several cell lines, including human colon cancer. }\end{array}$ & [56-58] \\
\hline 35 & D-Glucose & 34.781 & 3.34 & 21.1588 & 96 & N/A & \\
\hline 36 & D-Sorbitol & 34.972 & 6.79 & 43.05749 & 94 & N/A & \\
\hline 37 & $\beta$-D-Glucopyranose & 35.55 & 2.72 & 17.22668 & 98 & N/A & \\
\hline
\end{tabular}


Table 1. Cont.

\begin{tabular}{|c|c|c|c|c|c|c|c|}
\hline Peak & Name & $\mathbf{R}_{\mathrm{t}}$ & $\%$ Area & DW mg/g & Match Factor & Relation to Apoptosis & References \\
\hline 38 & $\begin{array}{l}\text { 3-Hexyl-7,8,9,10-tetrahydro- } \\
\text { 6,6,9-trimethyl-6H- } \\
\text { dibenzo(b,d)pyran-1-ol, }\end{array}$ & 35.887 & 1.07 & 6.810763 & 79 & Also called Synhexyl & \\
\hline 39 & Palmitic Acid & 35.887 & 1.07 & 6.810763 & 98 & $\begin{array}{l}\text { Reported to induce apoptosis in dozens of cancer cell } \\
\text { lines via MAPK and AMPK/Akt/mTOR, } \\
\text { miR-129-3p/Smad3, and estrogen receptor alpha } \\
\text { signaling pathways. }\end{array}$ & [59-61] \\
\hline 40 & Myoinositol & 36.795 & 18.69 & 118.5457 & 97 & $\begin{array}{l}\text { Reported to be involved in apoptosis induction in the } \\
\text { Arabidopsis plant. }\end{array}$ & [62] \\
\hline 41 & Caffeic acid & 37.066 & 0.50 & 3.155426 & 81 & $\begin{array}{l}\text { Reported to induce apoptosis and cell cycle arrest in } \\
\text { several cell lines, including human colon, breast, } \\
\text { nasopharyngeal carcinoma, melanoma, lung, } \\
\text { nasopharyngeal and others. It altered the } \\
\text { mTOR/PI3K/AKT signaling pathway and inactivated } \\
\text { NF-KB pathway. }\end{array}$ & [63-65] \\
\hline 42 & L-Rhamnose & 37.74 & 0.26 & 1.662177 & 85 & N/A & \\
\hline 43 & Stearic acid & 37.915 & 0.52 & 3.312062 & 91 & $\begin{array}{l}\text { Reported to arrest the cell cycle and induce apoptosis in } \\
\text { HepG2 and other cancer cell lines. }\end{array}$ & {$[66,67]$} \\
\hline 44 & Glyceryl-glycoside & 38.97 & 0.72 & 4.565657 & 94 & N/A & \\
\hline 45 & D-(+)-Trehalose & 43.451 & 1.31 & 8.317046 & 92 & Induced autophagy. & [68] \\
\hline 46 & $(2 R)-(E)$-Catechine & 44.747 & 0.55 & 3.465693 & 86 & N/A & \\
\hline 47 & (2R-cis)-Catechine & 45.142 & 0.08 & 0.496909 & 84 & $\mathrm{~N} / \mathrm{A}$ & \\
\hline 48 & $\beta$-Sitosterol & 53.782 & 0.19 & 1.17753 & 88 & $\begin{array}{l}\text { Also named phytosterol. Reported to induce apoptosis } \\
\text { and cell cycle arrest in HCT116, MCF-7, A549, and HeLa } \\
\text { cell lines. Altered the PI3K/Akt signaling pathway and } \\
\text { AMPK/PTEN/HSP90. }\end{array}$ & [69-71] \\
\hline 49 & Stigmasterol & 53.782 & 0.18 & 1.15534 & 90 & $\begin{array}{l}\text { Reported to lead to cell cycle arrest, } \\
\text { mitochondrial-mediated apoptosis, and inhibition of } \\
\text { JAK/STAT signaling pathway. It also inhibited cell } \\
\text { migration in human gastric cancer cells. }\end{array}$ & [72] \\
\hline 50 & Sucrose & 55.393 & 10.91285 & 69.21846 & 92 & $\mathrm{~N} / \mathrm{A}$ & \\
\hline
\end{tabular}




\subsection{GC-MS Analysis of the HTE}

The phytochemical profile of HTE was complemented by GC/MS metabolite profiling of derivatized extracts, as described in Section 2.4. A total of 50 novel identified metabolites in H. triquetrifolium were monitored (Table 1). Most of the compounds were terpenoids, organic acids, alcohols, and sugars. Interestingly, 21 compounds detected are associated with either anti-cancer, apoptosis induction, or cell cycle arrest activity (Figure 6 and Table 1). These potential active compounds compose $23.2 \%$ of the total amount of the detected chemicals.

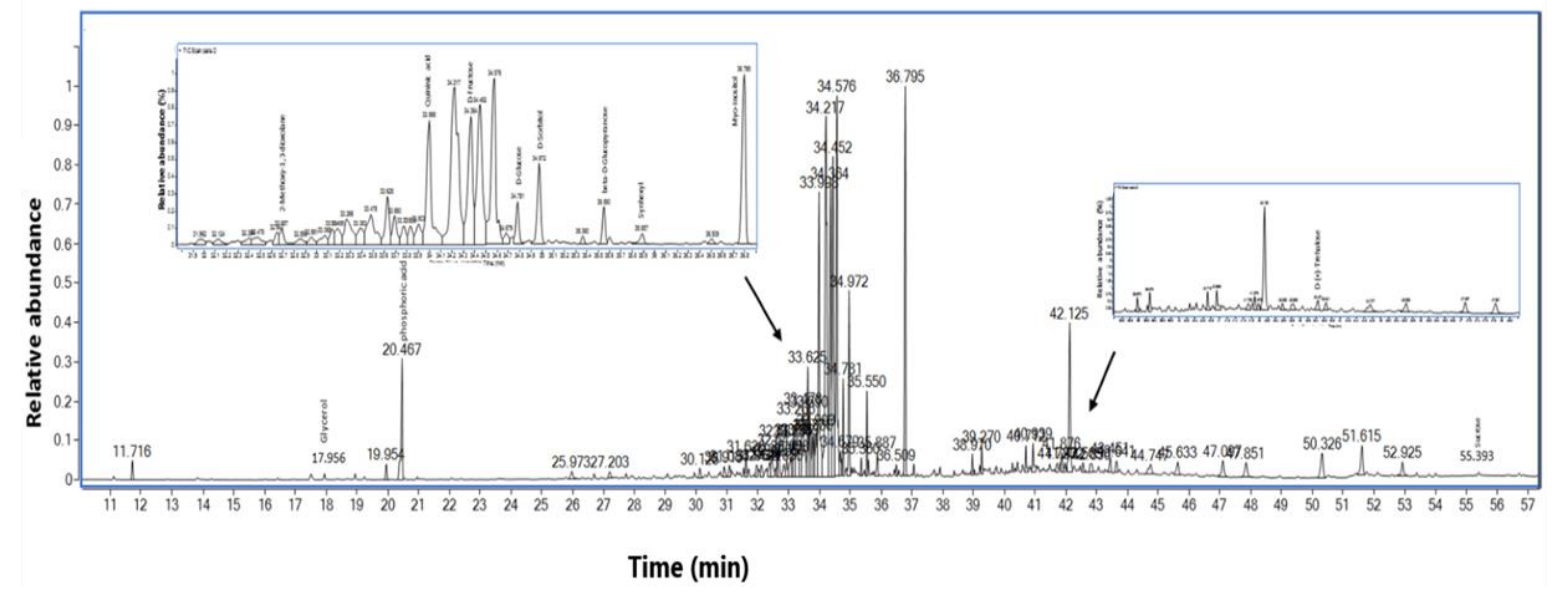

Figure 6. GC-MS chromatogram of the HTE. Major peaks are labeled with the compounds identified. Zoom; region of the elution of some compounds.

\section{Discussion}

The exploration of herbal medicines may present novel strategies for the treatment of CRC, which remains the second leading cause of cancer death. Herbal medicines such as garlic, onion, black fennel seeds, olive oil, olive leaves, and HTE are commonly prescribed for cancer treatment and prevention $[17,18]$.

In this in vitro study, HTE was found to be non-toxic up to $0.5 \mathrm{mg} / \mathrm{mL}$. Our study indicated that the treatment of a colon cancer cell line (HCT-116) with HTE extracts resulted in a significant induction of apoptosis, as detected by Annexin-v staining. The apoptotic effects of HTE were further confirmed by measuring caspase- 3 activity. Caspases are a family of proteases that mediate cell death; they play an important role in the process of apoptosis. Activated caspase-3 is the key catalyst of the apoptosis process. Treatment of HCT-116 cells with HTE extract resulted in a dose-dependent activation of caspase-3. Based on these results, HTE-induction of apoptosis was determined to be mediated, at least partially, by caspase-3 activation.

The release of cytochrome $\mathrm{c}$ from the mitochondria serves as a trigger for the formation of apoptosome, an oligomeric protein complex consisting of Apaf1, procaspase-9, and cytochrome c [73]. The formation of apoptosome leads, in turn, to the activation of caspase-3. NOXA is a member of the bcl-2 family and is described as a p53 target gene, serving as a candidate mediator for p53-induced apoptosis [74]. Both NOXA and Apaf-1 genes were selected for further analysis of the underlying mechanisms of HTE-induced apoptosis. However, RT-PCR analysis revealed that HTE extracts had no effect on the mRNA levels of Apaf-1 and NOXA, suggesting that apoptosis induction by HTE is not governed by the transcriptional regulation of these genes. Apoptosis is closely regulated by anti-apoptotic and pro-apoptotic effector molecules and can be mediated by several distinct pathways. Gene expression is often interpreted in terms of protein levels. Production and maintenance of cellular proteins require a remarkable series of linked processes from transcription, processing, and degradation of mRNA to the translation, localization, modification, and programmed destruction of the proteins themselves [75]. Based on the results obtained, where HTE had no effect at the transcriptional level of the tested mRNAs, the induction of apoptosis by HTE extracts is, most probably, at a post-transcriptional level. 
In addition, the effect of HTE extracts on the cell cycle progression was determined. The significant increase in the percentage of HCT-116 cells with a subG1 DNA content observed in the study suggests that this extract induced apoptosis and thereby disrupted the uncontrolled cell cycle progression.

GC/MS of the HTE extract was examined in order to detect bioactive compounds. Out of the 50 compounds detected, 21 compounds are associated with either anti-cancer, apoptosis induction, or cell cycle arrest activity. Most of the cell cycle arrest and apoptosis inducer compounds detected are phenols, terpenoids, fatty and organic acids, and alcohols. Indeed, plant extracts that contain phenolic compounds or long-chain fatty acids $[76,77]$ have been reported as potential anti-cancer agents $[78,79]$. The specific activity of each compound detected is summarized in Table 1. Further studies are required in order to evaluate the anti-cancer activity of these compounds individually and to determine whether they are effective as pure compounds or combined.

Further studies are needed to map the different genes involved and the specific cellular pathways that influence the induction of apoptosis by HTE. Identifying and isolating agents that can induce apoptosis and cell cycle arrest in cancer cells is a high priority. HTE extract seems to possess a potent therapeutic activity for colon cancer via cell cycle arrest and apoptosis induction. However, HTE's effect on untransformed cells needs to be further investigated before it can be used as an anti-cancer agent.

Author Contributions: S.M., S.K. (Sleman Kadan), S.K. (Said Khasib), and A.T. performed the experiments. Z.T. performed the GC/MS analysis. B.S. was involved in planning the study and revising the manuscript. D.G. was involved in designing the study and the supervision of S.M. H.Z. is the corresponding author, supervisor of the students involved, and main writer of the manuscript, which was done in consultation with all authors.

Funding: This research received no external funding.

Acknowledgments: The authors would like to acknowledge the Association of Arab Universities Research Fund, the Al-Qasemi and AAUP Research Foundations for providing financial support. This research received no external funding. S. Kadan thanks the Ministry of Science, Technology, and Space for the scholarship provided. The authors are thankful to Dan Cohen Hamus for his valuable technical assistance.

Conflicts of Interest: The authors declare no conflict of interest.

\section{References}

1. Mullan, F. Seasons of survival: Reflections of a physician with cancer. N. Engl. J. Med. 1985, 313, 270-273. [CrossRef] [PubMed]

2. Wang, Z.; Wang, N.; Chen, J.; Shen, J. Emerging glycolysis targeting and drug discovery from chinese medicine in cancer therapy. Evid.-Based Complement. Altern. Med. 2012, 2012, 873175. [CrossRef] [PubMed]

3. Costea, T.; Hudita, A.; Ciolac, O.A.; Galateanu, B.; Ginghina, O.; Costache, M.; Ganea, C.; Mocanu, M.M. Chemoprevention of Colorectal Cancer by Dietary Compounds. Int. J. Mol. Sci. 2018, 19, 3787. [CrossRef] [PubMed]

4. Deng, W.; Sui, H.; Wang, Q.; He, N.; Duan, C.; Han, L.; Li, Q.; Lu, M.; Lv, S. A Chinese herbal formula, Yi-Qi-Fu-Sheng, inhibits migration/invasion of colorectal cancer by down-regulating MMP-2/9 via inhibiting the activation of ERK/MAPK signaling pathways. BMC Complement. Altern. Med. 2013, 13, 65. [CrossRef] [PubMed]

5. Satia, J.A.; Littman, A.; Slatore, C.G.; Galanko, J.A.; White, E. Associations of herbal and specialty supplements with lung and colorectal cancer risk in the VITamins and Lifestyle study. Cancer Epidemiol. Biomark. Prev. 2009, 18, 1419-1428. [CrossRef] [PubMed]

6. Chen, Y.N.; Sharma, S.K.; Ramsey, T.M.; Jiang, L.; Martin, M.S.; Baker, K.; Adams, P.D.; Bair, K.W.; Kaelin, W.G., Jr. Selective killing of transformed cells by cyclin/cyclin-dependent kinase 2 antagonists. Proc. Natl. Acad. Sci. USA 1999, 96, 4325-4329. [CrossRef]

7. Mahadevan, D.; Plummer, R.; Squires, M.S.; Rensvold, D.; Kurtin, S.; Pretzinger, C.; Dragovich, T.; Adams, J.; Lock, V.; Smith, D.M.; et al. A phase I pharmacokinetic and pharmacodynamic study of AT7519, a cyclin-dependent kinase inhibitor in patients with refractory solid tumors. Ann. Oncol. 2011, 22, 2137-2143. [CrossRef]

8. Schoffski, P. Polo-like kinase (PLK) inhibitors in preclinical and early clinical development in oncology. Oncologist 2009, 14, 559-570. [CrossRef] 
9. Maiti, B.; Li, J.; de Bruin, A.; Gordon, F.; Timmers, C.; Opavsky, R.; Patil, K.; Tuttle, J.; Cleghorn, W.; Leone, G. Cloning and characterization of mouse E2F8, a novel mammalian E2F family member capable of blocking cellular proliferation. J. Biol. Chem. 2005, 280, 18211-18220. [CrossRef]

10. Yu, B.; Lane, M.E.; Wadler, S. SU9516, a cyclin-dependent kinase 2 inhibitor, promotes accumulation of high molecular weight E2F complexes in human colon carcinoma cells. Biochem. Pharmacol. 2002, 64, 1091-1100. [CrossRef]

11. Banerjee, D.; Gorlick, R.; Liefshitz, A.; Danenberg, K.; Danenberg, P.C.; Danenberg, P.V.; Klimstra, D.; Jhanwar, S.; Cordon-Cardo, C.; Fong, Y.; et al. Levels of E2F-1 expression are higher in lung metastasis of colon cancer as compared with hepatic metastasis and correlate with levels of thymidylate synthase. Cancer Res. 2000, 60, 2365-2367. [PubMed]

12. Kaur, M.; Singh, R.P.; Gu, M.; Agarwal, R.; Agarwal, C. Grape seed extract inhibits in vitro and in vivo growth of human colorectal carcinoma cells. Clin. Cancer Res. 2006, 12, 6194-6202. [CrossRef] [PubMed]

13. Yasui, W.; Fujimoto, J.; Suzuki, T.; Ono, S.; Naka, K.; Yokozaki, H.; Tahara, E. Expression of cell-cycle-regulating transcription factor E2F-1 in colorectal carcinomas. Pathobiology 1999, 67, 174-179. [CrossRef] [PubMed]

14. Chen, Z.Y.; Istfan, N.W. Docosahexaenoic acid is a potent inducer of apoptosis in HT-29 colon cancer cells. Prostaglandins Leukot. Essent. Fatty Acids 2000, 63, 301-308. [CrossRef]

15. Otto, T.; Sicinski, P. Cell cycle proteins as promising targets in cancer therapy. Nat. Rev. Cancer 2017, 17, 93-115. [CrossRef]

16. Fearon, E.R.; Vogelstein, B. A genetic model for colorectal tumorigenesis. Cell 1990, 61, 759-767. [CrossRef]

17. Zaid, H.; Silbermann, M.; Ben-Arye, E.; Saad, B. Greco-arab and islamic herbal-derived anticancer modalities: From tradition to molecular mechanisms. Evid.-Based Complement. Altern. Med. 2012, 2012, 349040. [CrossRef]

18. Chandra, S.A.; Nolan, M.W.; Malarkey, D.E. Chemical carcinogenesis of the gastrointestinal tract in rodents: An overview with emphasis on NTP carcinogenesis bioassays. Toxicol. Pathol. 2010, 38, 188-197. [CrossRef]

19. Volanis, D.; Kadiyska, T.; Galanis, A.; Delakas, D.; Logotheti, S.; Zoumpourlis, V. Environmental factors and genetic susceptibility promote urinary bladder cancer. Toxicol. Lett. 2010, 193, 131-137. [CrossRef]

20. Rouis, Z.; Abid, N.; Koudja, S.; Yangui, T.; Elaissi, A.; Cioni, P.L.; Flamini, G.; Aouni, M. Evaluation of the cytotoxic effect and antibacterial, antifungal, and antiviral activities of Hypericum triquetrifolium Turra essential oils from Tunisia. BMC Complement. Altern. Med. 2013, 13, 24. [CrossRef]

21. Li, X.M.; Luo, X.G.; He, J.F.; Wang, N.; Zhou, H.; Yang, P.L.; Zhang, T.C. Induction of apoptosis in human cervical carcinoma HeLa cells by active compounds from Hypericum ascyron L. Oncol. Lett. 2018, 15, 3944-3950. [PubMed]

22. Qiu, D.; Zhou, M.; Lin, T.; Chen, J.; Wang, G.; Huang, Y.; Jiang, X.; Tian, W.; Chen, H. Cytotoxic Components from Hypericum elodeoides Targeting RXRalpha and Inducing HeLa Cell Apoptosis through Caspase-8 Activation and PARP Cleavage. J. Nat. Prod. 2019, 82, 1072-1080. [CrossRef] [PubMed]

23. Mirmalek, S.A.; Azizi, M.A.; Jangholi, E.; Yadollah-Damavandi, S.; Javidi, M.A.; Parsa, Y.; Parsa, T.; Salimi-Tabatabaee, S.A.; Ghasemzadeh Kolagar, H.; Alizadeh-Navaei, R. Cytotoxic and apoptogenic effect of hypericin, the bioactive component of Hypericum perforatum on the MCF-7 human breast cancer cell line. Cancer Cell Int. 2016, 16, 3. [CrossRef] [PubMed]

24. Sarimahmut, M.; Balikci, N.; Celikler, S.; Ari, F.; Ulukaya, E.; Guleryuz, G.; Ozel, M.Z. Evaluation of genotoxic and apoptotic potential of Hypericum adenotrichum Spach. in vitro. Regul. Toxicol. Pharmacol. 2016, 74, 137-146. [CrossRef] [PubMed]

25. Hamzeloo-Moghadam, M.; Khalaj, A.; Malekmohammadi, M. Cytotoxic Activity and Apoptosis Induction of Hypericum scabrum L. Iran. Red Crescent Med. J. 2015, 17, e19453. [CrossRef] [PubMed]

26. Zhuang, Q.; Li, J.; Chen, Y.; Lin, J.; Lai, F.; Chen, X.; Lin, X.; Peng, J. Ethyl acetate extract of Hypericum japonicum induces apoptosis via the mitochondria-dependent pathway in vivo and in vitro. Mol. Med. Rep. 2015, 12, 4851-4858. [CrossRef] [PubMed]

27. Kadan, S.; Sasson, Y.; Saad, B.; Zaid, H. Gundelia tournefortii Antidiabetic Efficacy: Chemical Composition and GLUT4 Translocation. Evid.-Based Complement. Altern. Med. 2018, 2018, 8294320. [CrossRef]

28. Saad, B.; Azaizeh, H.; Said, O. Tradition and perspectives of arab herbal medicine: A review. Evid.-Based Complement. Altern. Med. 2005, 2, 475-479. [CrossRef]

29. Mintz-Oron, S.; Mandel, T.; Rogachev, I.; Feldberg, L.; Lotan, O.; Yativ, M.; Wang, Z.; Jetter, R.; Venger, I.; Adato, A.; et al. Gene expression and metabolism in tomato fruit surface tissues. Plant Physiol. 2008, 147, 823-851. [CrossRef] 
30. Kadan, S.; Saad, B.; Sasson, Y.; Zaid, H. In vitro evaluation of anti-diabetic activity and cytotoxicity of chemically analysed Ocimum basilicum extracts. Food Chem. 2016, 196, 1066-1074. [CrossRef]

31. Kadan, S.; Saad, B.; Sasson, Y.; Zaid, H. In Vitro Evaluations of Cytotoxicity of Eight Antidiabetic Medicinal Plants and Their Effect on GLUT4 Translocation. Evid.-Based Complement. Altern. Med. 2013, 2013, 549345. [CrossRef] [PubMed]

32. Saydam, O.; Glauser, D.L.; Heid, I.; Turkeri, G.; Hilbe, M.; Jacobs, A.H.; Ackermann, M.; Fraefel, C. Herpes simplex virus 1 amplicon vector-mediated siRNA targeting epidermal growth factor receptor inhibits growth of human glioma cells in vivo. Mol. Ther. 2005, 12, 803-812. [CrossRef] [PubMed]

33. Masters, S.C.; Fu, H. 14-3-3 proteins mediate an essential anti-apoptotic signal. J. Biol. Chem. 2001, 276, 45193-45200. [CrossRef] [PubMed]

34. Napoli, E.; Wong, S.; Hung, C.; Ross-Inta, C.; Bomdica, P.; Giulivi, C. Defective mitochondrial disulfide relay system, altered mitochondrial morphology and function in Huntington's disease. Hum. Mol. Genet. 2013, 22, 989-1004. [CrossRef]

35. Hershko, T.; Ginsberg, D. Up-regulation of Bcl-2 homology 3 (BH3)-only proteins by E2F1 mediates apoptosis. J. Biol. Chem. 2004, 279, 8627-8634. [CrossRef]

36. Mukherjee, A.; Adhikari, N.; Jha, T. A pentanoic acid derivative targeting matrix metalloproteinase-2 (MMP-2) induces apoptosis in a chronic myeloid leukemia cell line. Eur. J. Med. Chem. 2017, 141, 37-50. [CrossRef]

37. Narayanan, A.; Baskaran, S.A.; Amalaradjou, M.A.; Venkitanarayanan, K. Anticarcinogenic properties of medium chain fatty acids on human colorectal, skin and breast cancer cells in vitro. Int. J. Mol. Sci. 2015, 16, 5014-5027. [CrossRef]

38. Carvalho, C.M.; Menezes, P.F.; Letenski, G.C.; Praes, C.E.; Feferman, I.H.; Lorencini, M. In vitro induction of apoptosis, necrosis and genotoxicity by cosmetic preservatives: Application of flow cytometry as a complementary analysis by NRU. Int. J. Cosmet. Sci. 2012, 34, 176-182. [CrossRef]

39. Smith, K.R.; Granberry, M.; Tan, M.C.B.; Daniel, C.L.; Gassman, N.R. Dihydroxyacetone induces G2/M arrest and apoptotic cell death in A375P melanoma cells. Environ. Toxicol. 2018, 33, 333-342. [CrossRef]

40. Yilmaz, B.; Karabay, A.Z. Food Additive Sodium Benzoate (NaB) Activates NFkappaB and Induces Apoptosis in HCT116 Cells. Molecules 2018, 23, 723. [CrossRef]

41. Forsey, R.J.; Shahidullah, H.; Sands, C.; McVittie, E.; Aldridge, R.D.; Hunter, J.A.; Howie, S.E. Epidermal Langerhans cell apoptosis is induced in vivo by nonanoic acid but not by sodium lauryl sulphate. Br. J. Dermatol. 1998, 139, 453-461. [CrossRef] [PubMed]

42. Jeong, M.; Kim, H.M.; Kim, H.J.; Choi, J.H.; Jang, D.S. Kudsuphilactone B, a nortriterpenoid isolated from Schisandra chinensis fruit, induces caspase-dependent apoptosis in human ovarian cancer A2780 cells. Arch. Pharm. Res. 2017, 40, 500-508. [CrossRef] [PubMed]

43. Lee, T.K.; Roh, H.S.; Yu, J.S.; Baek, J.; Lee, S.; Ra, M.; Kim, S.Y.; Baek, K.H.; Kim, K.H. Pinecone of Pinus koraiensis Inducing Apoptosis in Human Lung Cancer Cells by Activating Caspase-3 and its Chemical Constituents. Chem. Biodivers. 2017, 14. [CrossRef] [PubMed]

44. Sitarek, P.; Skala, E.; Toma, M.; Wielanek, M.; Szemraj, J.; Skorski, T.; Bialas, A.J.; Sakowicz, T.; Kowalczyk, T.; Radek, M.; et al. Transformed Root Extract of Leonurus sibiricus Induces Apoptosis through Intrinsic and Extrinsic Pathways in Various Grades of Human Glioma Cells. Pathol. Oncol. Res. 2017, 23, 679-687. [CrossRef]

45. Wang, X.N.; Wang, K.Y.; Zhang, X.S.; Yang, C.; Li, X.Y. 4-Hydroxybenzoic acid (4-HBA) enhances the sensitivity of human breast cancer cells to adriamycin as a specific HDAC6 inhibitor by promoting HIPK2/p53 pathway. Biochem. Biophys. Res. Commun. 2018, 504, 812-819. [CrossRef]

46. Jin, Z.; Wang, W.F.; Huang, J.P.; Wang, H.M.; Ju, H.X.; Chang, Y. Dryocrassin ABBA Induces Apoptosis in Human Hepatocellular Carcinoma HepG2 Cells Through a Caspase-Dependent Mitochondrial Pathway. Asian Pac. J. Cancer Prev. 2016, 17, 1823-1828. [CrossRef]

47. Lee,H.A.; Lee, J.H.; Han, J.S. 2,7"-Phloroglucinol-6,6'-bieckol protects INS-1 cells against high glucose-induced apoptosis. Biomed. Pharmacother. 2018, 103, 1473-1481. [CrossRef]

48. Park, C.; Cha, H.J.; Hong, S.H.; Kim, G.Y.; Kim, S.; Kim, H.S.; Kim, B.W.; Jeon, Y.J.; Choi, Y.H. Protective Effect of Phloroglucinol on Oxidative Stress-Induced DNA Damage and Apoptosis through Activation of the Nrf2/HO-1 Signaling Pathway in HaCaT Human Keratinocytes. Mar. Drugs 2019, 17, 225. [CrossRef]

49. Chang, L.C.; Tsai, T.R.; Wang, J.J.; Lin, C.N.; Kuo, K.W. The rhamnose moiety of solamargine plays a crucial role in triggering cell death by apoptosis. Biochem. Biophys. Res. Commun. 1998, 242, 21-25. [CrossRef] 
50. Gong, J.; Zhou, S.; Yang, S. Vanillic Acid Suppresses HIF-1alpha Expression via Inhibition of mTOR/p70S6K/4E-BP1 and Raf/MEK/ERK Pathways in Human Colon Cancer HCT116 Cells. Int. J. Mol. Sci. 2019, 20, 465. [CrossRef]

51. Kakkar, S.; Bais, S. A review on protocatechuic Acid and its pharmacological potential. ISRN Pharmacol. 2014, 2014, 952943. [CrossRef] [PubMed]

52. Lin, M.C.; Ou, T.T.; Chang, C.H.; Chan, K.C.; Wang, C.J. Correction to Protocatechuic Acid Inhibits Oleic Acid-Induced Vascular Smooth Muscle Cell Proliferation through Activation of AMP-Activated Protein Kinase and Cell Cycle Arrest in G0/G1 Phase. J. Agric. Food Chem. 2015, 63, 4003. [CrossRef] [PubMed]

53. Tsao, S.M.; Hsia, T.C.; Yin, M.C. Protocatechuic acid inhibits lung cancer cells by modulating FAK, MAPK, and NF-kappaB pathways. Nutr. Cancer 2014, 66, 1331-1341. [CrossRef] [PubMed]

54. Xie, Z.; Guo, Z.; Wang, Y.; Lei, J.; Yu, J. Protocatechuic acid inhibits the growth of ovarian cancer cells by inducing apoptosis and autophagy. Phytother. Res. 2018, 32, 2256-2263. [CrossRef] [PubMed]

55. Yip, E.C.; Chan, A.S.; Pang, H.; Tam, Y.K.; Wong, Y.H. Protocatechuic acid induces cell death in HepG2 hepatocellular carcinoma cells through a c-Jun N-terminal kinase-dependent mechanism. Cell Biol. Toxicol. 2006, 22, 293-302. [CrossRef]

56. Kianmehr, Z.; Khorsandi, K.; Mohammadi, M.; Hosseinzadeh, R. Low-level laser irradiation potentiates anticancer activity of p-coumaric acid against human malignant melanoma cells. Melanoma Res. 2019. [CrossRef]

57. Pei, K.; Ou, J.; Huang, J.; Ou, S. p-Coumaric acid and its conjugates: Dietary sources, pharmacokinetic properties and biological activities. J. Sci. Food Agric. 2016, 96, 2952-2962. [CrossRef]

58. Sharma, S.H.; Rajamanickam, V.; Nagarajan, S. Supplementation of p-coumaric acid exhibits chemopreventive effect via induction of Nrf2 in a short-term preclinical model of colon cancer. Eur. J. Cancer Prev. 2019, 28, 472-482. [CrossRef]

59. Liang, Z.; Yuan, Z.; Guo, J.; Wu, J.; Yi, J.; Deng, J.; Shan, Y. Ganoderma lucidum Polysaccharides Prevent Palmitic Acid-Evoked Apoptosis and Autophagy in Intestinal Porcine Epithelial Cell Line via Restoration of Mitochondrial Function and Regulation of MAPK and AMPK/Akt/mTOR Signaling Pathway. Int. J. Mol. Sci. 2019, 20, 478. [CrossRef]

60. Sun, Y.; Yang, J.; Liu, W.; Yao, G.; Xu, F.; Hayashi, T.; Onodera, S.; Ikejima, T. Attenuating effect of silibinin on palmitic acid-induced apoptosis and mitochondrial dysfunction in pancreatic beta-cells is mediated by estrogen receptor alpha. Mol. Cell. Biochem. 2019, 460, 81-92. [CrossRef]

61. Zou, Y.; Kong, M. Tetrahydroxy stilbene glucoside alleviates palmitic acid-induced inflammation and apoptosis in cardiomyocytes by regulating miR-129-3p/Smad3 signaling. Cell. Mol. Biol. Lett. 2019, 24, 5. [CrossRef] [PubMed]

62. Meng, P.H.; Raynaud, C.; Tcherkez, G.; Blanchet, S.; Massoud, K.; Domenichini, S.; Henry, Y.; Soubigou-Taconnat, L.; Lelarge-Trouverie, C.; Saindrenan, P.; et al. Crosstalks between myo-inositol metabolism, programmed cell death and basal immunity in Arabidopsis. PLoS ONE 2009, 4, e7364. [CrossRef] [PubMed]

63. Liang, Y.; Feng, G.; Wu, L.; Zhong, S.; Gao, X.; Tong, Y.; Cui, W.; Qin, Y.; Xu, W.; Xiao, X.; et al. Caffeic acid phenethyl ester suppressed growth and metastasis of nasopharyngeal carcinoma cells by inactivating the NF-kappaB pathway. Drug Des. Dev. Ther. 2019, 13, 1335-1345. [CrossRef] [PubMed]

64. Motawi, T.K.; Abdelazim, S.A.; Darwish, H.A.; Elbaz, E.M.; Shouman, S.A. Modulation of Tamoxifen Cytotoxicity by Caffeic Acid Phenethyl Ester in MCF-7 Breast Cancer Cells. Oxid. Med. Cell. Longev. 2016, 2016, 3017108. [CrossRef]

65. Zeng, N.; Hongbo, T.; Xu, Y.; Wu, M.; Wu, Y. Anticancer activity of caffeic acid nbutyl ester against A431 skin carcinoma cell line occurs via induction of apoptosis and inhibition of the mTOR/PI3K/AKT signaling pathway. Mol. Med. Rep. 2018, 17, 5652-5657.

66. Khan, A.A.; Alanazi, A.M.; Jabeen, M.; Chauhan, A.; Abdelhameed, A.S. Design, synthesis and in vitro anticancer evaluation of a stearic acid-based ester conjugate. Anticancer Res. 2013, 33, 2517-2524.

67. Liu, Y.; Cheng, Y.; Li, J.; Wang, Y.; Liu, Y. Epoxy Stearic Acid, an Oxidative Product Derived from Oleic Acid, Induces Cytotoxicity, Oxidative Stress, and Apoptosis in HepG2 Cells. J. Agric. Food Chem. 2018, 66, 5237-5246. [CrossRef]

68. Rusmini, P.; Cortese, K.; Crippa, V.; Cristofani, R.; Cicardi, M.E.; Ferrari, V.; Vezzoli, G.; Tedesco, B.; Meroni, M.; Messi, E.; et al. Trehalose induces autophagy via lysosomal-mediated TFEB activation in models of motoneuron degeneration. Autophagy 2019, 15, 631-651. [CrossRef] 
69. Alvarez-Sala, A.; Attanzio, A.; Tesoriere, L.; Garcia-Llatas, G.; Barbera, R.; Cilla, A. Apoptotic effect of a phytosterol-ingredient and its main phytosterol (beta-sitosterol) in human cancer cell lines. Int. J. Food Sci. Nutr. 2019, 70, 323-334. [CrossRef]

70. Cao, Z.Q.; Wang, X.X.; Lu, L.; Xu, J.W.; Li, X.B.; Zhang, G.R.; Ma, Z.J.; Shi, A.C.; Wang, Y.; Song, Y.J. $\beta$-Sitosterol and Gemcitabine Exhibit Synergistic Anti-pancreatic Cancer Activity by Modulating Apoptosis and Inhibiting Epithelial-Mesenchymal Transition by Deactivating Akt/GSK-3beta Signaling. Front. Pharmacol. 2018, 9, 1525. [CrossRef]

71. Shin, E.J.; Choi, H.K.; Sung, M.J.; Park, J.H.; Chung, M.Y.; Chung, S.; Hwang, J.T. Anti-tumour effects of beta-sitosterol are mediated by AMPK/PTEN/HSP90 axis in AGS human gastric adenocarcinoma cells and xenograft mouse models. Biochem. Pharmacol. 2018, 152, 60-70. [CrossRef] [PubMed]

72. Li, K.; Yuan, D.; Yan, R.; Meng, L.; Zhang, Y.; Zhu, K. Stigmasterol exhibits potent antitumor effects in human gastric cancer cells mediated via inhibition of cell migration, cell cycle arrest, mitochondrial mediated apoptosis and inhibition of JAK/STAT signalling pathway. J. BUON 2018, 23, 1420-1425. [PubMed]

73. Fadeel, B.; Ottosson, A.; Pervaiz, S. Big wheel keeps on turning: Apoptosome regulation and its role in chemoresistance. Cell Death Differ. 2008, 15, 443-452. [CrossRef] [PubMed]

74. Oda, E.; Ohki, R.; Murasawa, H.; Nemoto, J.; Shibue, T.; Yamashita, T.; Tokino, T.; Taniguchi, T.; Tanaka, N. Noxa, a BH3-only member of the Bcl-2 family and candidate mediator of p53-induced apoptosis. Science 2000, 288, 1053-1058. [CrossRef] [PubMed]

75. Vogel, C.; Marcotte, E.M. Insights into the regulation of protein abundance from proteomic and transcriptomic analyses. Nat. Rev. Genet. 2012, 13, 227-232. [CrossRef]

76. Adebayo, I.A.; Gagman, H.A.; Balogun, W.G.; Adam, M.A.A.; Abas, R.; Hakeem, K.R.; Nik Him, N.; Samian, M.R.B.; Arsad, H. Detarium microcarpum, Guiera senegalensis, and Cassia siamea Induce Apoptosis and Cell Cycle Arrest and Inhibit Metastasis on MCF7 Breast Cancer Cells. Evid.-Based Complement. Altern. Med. 2019, 2019, 6104574.

77. Intisar, A.; Zhang, L.; Luo, H.; Kiazolu, J.B.; Zhang, R.; Zhang, W. Anticancer constituents and cytotoxic activity of methanol-water extract of Polygonum bistorta L. Afr. J. Tradit. Complement. Altern. Med. 2012, 10, 53-59. [CrossRef]

78. Cevik, D.; Kan, Y.; Kirmizibekmez, H. Mechanisms of action of cytotoxic phenolic compounds from Glycyrrhiza iconica roots. Phytomedicine 2019, 58, 152872. [CrossRef]

79. Owen, R.W.; Giacosa, A.; Hull, W.E.; Haubner, R.; Spiegelhalder, B.; Bartsch, H. The antioxidant/anticancer potential of phenolic compounds isolated from olive oil. Eur. J. Cancer 2000, 36, 1235-1247. [CrossRef]

Sample Availability: Samples of the compounds are not available from the authors.

(C) 2019 by the authors. Licensee MDPI, Basel, Switzerland. This article is an open access article distributed under the terms and conditions of the Creative Commons Attribution (CC BY) license (http://creativecommons.org/licenses/by/4.0/). 